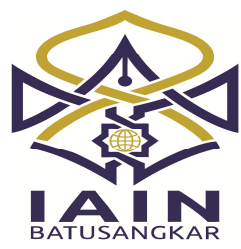

\title{
The Development of Authentic Assessment Rubric on History of Islamic Culture Subject at Islamic Education Department of IAIN Batusangkar
}

\author{
Romi Maimori*) \\ Institut Agama Islam Negeri Batusangkar, \\ Sumatera Barat, Indonesia \\ E-mail: maimori78@gmail.com
}

\begin{abstract}
This research is motivated by the fact that there is no standardized rubric in assessing students' performance either in performing the duties or in measuring the ability of students, especially for the subject of History of Islamic Culture taught to the students of Islamic Religious Education at IAIN Batusangkar. This research is a development research using Instructional Development Institute (IDI) model. The development procedure starts from planning, in the form of preliminary research and information gathering, until expert validation and product practice test. In the stage of expert validation, there are three aspects reviewed in the rubric developed, such as the material, construction and language aspects. Then, based on the three experts' validation results, it is shown that this authentic scoring rubric has very valid criteria on material aspects with an average of 3.57. In aspects of construction rubric authentic assessment also has a very valid criteria with an average of 3.67 while the language aspect obtained an average of 3.23 with the category is very valid. Hence, overall an authentic scoring rubric developed based on expert validation results has a very valid criterion with an average value of 3.53, whereas the authentic assessment rubric practicality analysis is known that this rubric is very practical to use, with a practicality value of 890.63 and an average practical value of 89.06 with a very practical category.
\end{abstract}

Key Words: Development, Authentic Asssessment Rubric, History of Islamic Culture subject.

\section{PENDAHULUAN}

Penilaian merupakan hal yang sangat urgen dalam sebuah proses pembelajaran, karena keberhasilan sebuah proses pendidikan akan diketahui dari pelaksanaan penilaian dengan standar yang telah ditetapkan. Untuk itu penilaiandalam sebuah proses pembelajaran harus dilakukan secara komprehensif atau menyeluruh. Dikatakan komprehensif karena kompetensi mahasiswa tidak hanya dilihat pada akhir proses saja tetapi juga harus pada saat proses pembelajaran berlangsung, setidaknya inilah alasan kenapa penting sebuah penilaian dalam sebuah proses pembelajaran.
Penilaian terhadap proses dan hasil pembelajaran dilakukan oleh dosen sebagai bagian integral dari proses kegiatan pembelajaran dengan tujuan untuk menilai efektivitas dan efisiensi kegiatan pengajaran sebagai bahan untuk perbaikan dan penyempurnaan program pembelajaran dengan melibatkan semua dimensi pada setiap kegiatan pembelajaran itu sendiri. Memperhatikan pentingnya penilaian dengan melihat semua aspek yang terlibat dalam pelaksanaan pembelajaran ditawarkan sebuah bentuk penilaian yaitu penilaian otentik. Penilaian otentik adalah proses yang sistematis dan berkesinambungan untuk mengumpulkan informasi tentang keberhasilan belajar 
mahasiswa dan bermanfaat untuk meningkatkan efektivitas pembelajaran.

Secara implisit ada tiga hal yang menjadi alasan mengapa pada saat ini perlunya sebuah penilaian otentik adalah karena adanya ketidakpuasan terhadap tes beropsi, para pendukung penilaian kinerja beranggapan bahwa tes beropsi hanya menggambarkan kemampuan mahasiswa secara parsial, sehingga tidak bisa melihat kemampuan berfikirnya secara utuh, selain itu tes beropsi memiliki daya surprise yang rendah karena mahasiswa cuma diminta untuk memilih respons yang telah disediakan.

Penilaian otentik lebih sering dinyatakan sebagai penilaian berbasis kinerja (Performance based assesment) dan ada juga yang menyebutnya sebagai penilaian alternatif (Alternative assessment) karena mahasiswa diminta untuk menampilkan tugas (Task), demikian juga halnya dalam mata kuliah materi SKI dan pembelajarannya mahasiswa diminta untuk menampilkan tugas-tugas mereka sebagai calon guru dengan memperhatikan semua kompetensi yang harus dimiliki oleh seorang guru dengan menampilkan metode pembelajaran dengan materi-materi/silabus Sejarah Kebudayaan Islam yang diajarkan di Madrasah baik tingkat Madrasah Tsanawiyah (MT maupun Madrasah Aliyah (MA).

Mata kuliah Materi SKI dan pembelajarannya adalah mata kuliah yang diajarkan pada juruan Pendidikan Agama Islam dengan kompetensi yang diharapkan kepada mahasiswa berupa penguasaan materi Sejarah Kebudayaan Islam yang ada di madrasah, mata kuliah ini adalah mata kuliah wajib diambil oleh setiap mahasiswa yang ada di jurusan Pendidikan Agama Islam dan merupakan mata kuliah keprofesionalan yang mendukung visi, misi dan tujuan jurusanPendidikan Agama Islam yaitu menjadikan tenaga pendidik yang Unggul, Berkualitas dan Kompetitif dalam Bidang Pendidikan Agama Islam pada jenjang pendidikan dasar dan menengah Berbasis Teknologi Modern.

Pada proses pelaksanaan pembelajaran belum adanya keseragaman dosen dalam melakukan penilaian terkait dengan mata kuliah yang mempunyai standar kompetensi yang sama atau mata kuliah yang mempunyai bidang kajian yang sama, cenderung mempunyai standar penilaian masing-masing, terhadap tugas dan performan mahasiswa dalam melakukan praktek terkait dengan kompetensinya sebagai calon pendidik PAI baik di sekolah dan di Madrasah dengan melakukan penilaian secara komprehensif baik pengetahuan, sikap maupun keterampilan mahasiswa sesuai dengan kompetensi yang diharapkan, Untuk itu penting kiranya penyamaan standar oleh dosen pengampu mata kuliah yang mempunyai standar kompetensi yang searah, yaitu berupa rubrik penilaian otentik.

Dalam Permendikbud No. 66 tahun 2013 tentang standar penilaian, dinyatakan bahwa penilaian otentik adalah penilain yang dilakukan secara komprehensif untuk menilai mulai dari input (masukan), proses, dan output (keluaran). Berdasarkan hal itu penilaian ini sangat cocok untuk mata kuliah materi SKI dan pembelajarannya atau mata kuliah yang menekankan dalam mengapungkan skill mahasiswa pada kompetensi profesional dan paedagogik, karena penilaian otentik merupakan sebuah instrumen penilaian yang mana para mahasiswa nanti akan diminta untuk menampilkan tugas pada situasi yang sesungguhnya dan mendemonstrasikan penerapan keterampilan sebagai implementasi pengetahuan yang telah mereka miliki.

Pada pelaksaan proses pembelajaran seorang dosen harus mengajukan pertanyaan kepada dirinya sendiri, khususnya yang berkaitan dengan: pengetahuan, sikap dan keterampilan apa yang akan dinilai dalam proses pembelajarannya. Berdasarkan pemikiran itulah penulis ingin mencoba menyusun 
dan mengembangan sebuah rubrik penilaian yaitu penilaian otentik agar penulis sebagai dosen yang mengajar pada mata kuliah materi SKI dan pembelajarannya memiliki sebuah instrumen peniliaian yang lebih baik dalam mengukur kompetensi mahasiswa secara komprehensif, yaitu dengan mencoba melakukan penelitian pengembangan dengan judul Pengembangan Rubrik Penilaian Otentik pada Mata Kuliah Materi SKI dan Pembelajarannya pada jurusan Pendidikan Agama Islam IAIN Batusangkar"

\section{Rumusan Masalah}

Berdasarkan latar belakang masalah yang dikemukakan di atas, rumusan masalah dalam penelitian ini adalah apakah rubrik penilaian otentik valid dan praktis untuk digunakan dalam mengukur performance mahasiswa pada mata kuliah materi SKI dan pembelajarannya mahasiswa Jurusan Pendidikan Agama Islam, dan apakah rubrik penilaian otentik yang telah direvisi sesuai dengan saran validator dapat diterima untuk digunakan sebagai instrumen baku dalam penilaian perkuliahan.

\section{Tujuan Pengembangan} adalah:

Tujuan penelitian pengembangan ini

1. Lahirnya sebuah rubrik penilaian otentik yang valid dalam mengukur performance mahasiswa dalam mata kuliah materi SKI dan Pembelajarannya.

2. Lahirnya sebuah rubrik yang valid dalam menilai kemampuan dan kinerja mahasiswa dalam bentuk otentik assessment pada mata kuliah materi SKI dan pembelajarannya secara komprehensif.

\section{Spesifikasi Produk yang diharapkan}

Produk yang diharapkan secara spesifik dalam penelitian ini adalah sebuah instrumen penilaian berupa rubrik penilaian otentik yang akan dijadikan acuan bagi dosen dalam menilaian mahasiswa dalam mata kuliah materi SKI dan pembelajarannya dan rubrik yang dikembangkan akan rubrik ini juga diharapkan mampu menilai performance mahasiswa oleh teman sekelasnya dalam bentuk penilaian teman sejawat.

\section{Pentingnya Pengembangan}

Hasil penelitian ini diharapkan dapat bermanfaat dalam proses pembelajaran khusunya mata kuliah SKI dan pembelajarannya, di antaranya:

1. Tersedianya format rubrik penilaian dengan standar yang telah handal terpercaya untuk mengukur kemampuan performance mahasiswa dalam mata kuliah Materi SKI dan Pembelajarannya pada mahasiswa program studi Pendidikan Agama Islam.

2. Mahasiswa mengetahui dan mendapatkan informasi tentang standar penilaian terhadap kemampuan yang akandibangun.

3. Tim dosen memiliki acuan bersama terhadap standar yang digunakan dalam melalukan penilaian terhadap kemampuan mahasiswa yang mengikuti mata kuliah materi SKI dan pembelajarannya.

4. Tersedianya rubrik penilaian teman sejawat bagi mahasiswa dalam menilai performance temannya yang tampil praktek.

\section{METODE PENELITIAN}

Penelitian ini menggunakan metode penelitian pengembangan (research and development) yaitu metode penelitian yang digunakan untuk menghasilkan produk tertentu dan menguji keefektifan produk tersebut (Sugiyono, 2010:297)yang bertujuan untuk diarahkan untuk menemukan, merumuskan, memperbaiki, mengembangkan, menghasilkan, menguji keefektifan produk, model, 
metode/strategi/cara, jasa, prosedur tertentu yang lebih unggul, baru, efektif, produktif dan bermakna.

\section{Model Pengembangan}

Dalam pengembangan rubrik penilaian otentik ini, digunakan model prosedural yaitu: model yang bersifat deskriptif dengan menggariskan langkah-langkah yang harus diikuti untuk menghasilkan produk dan Model pengembangan dalam penelitian ini menggunakan model Instructional Development Institute (IDI), model ini merupakan hasil konsorsium antar perguruan tinggi di USA yang dikenal dengan University Consorsium Instructional Development And Technology (UCIDT). www.modelpembelajaran-idi.html/co.id

\begin{tabular}{|c|c|c|c|}
\hline & $\begin{array}{l}\text { Identify } \\
\text { problem }\end{array}$ & $\begin{array}{l}\text { Analyze } \\
\text { setting }\end{array}$ & $\begin{array}{l}\text { Organize } \\
\text { managemen } \\
\mathrm{t}\end{array}$ \\
\hline Demlle & $\begin{array}{l}\text { Ases needs } \\
\text { Establish } \\
\text { Priorities } \\
\text { State } \\
\text { problem }\end{array}$ & $\begin{array}{c}\text { Audience } \\
\text { Conditions } \\
\text { Relevant } \\
\text { resources } \\
\perp\end{array}$ & $\begin{array}{c}\text { Task } \\
\text { Responsibil } \\
\text { ities } \\
\text { Timelines }\end{array}$ \\
\hline
\end{tabular}

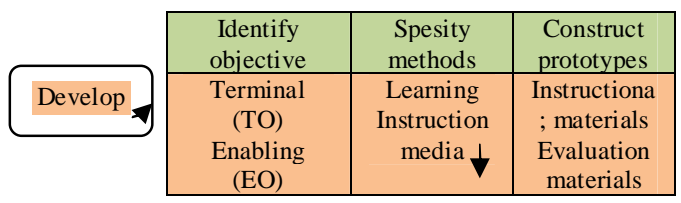

\begin{tabular}{|c|c|c|c|}
\hline Evaluate & $\begin{array}{c}\text { Tes } \\
\text { tryout }\end{array}$ & $\begin{array}{c}\text { Analyze } \\
\text { resuts }\end{array}$ & $\begin{array}{c}\text { Implement/ } \\
\text { recycle }\end{array}$ \\
\cline { 2 - 4 } & $\begin{array}{c}\text { Conduct } \\
\text { tryout } \\
\text { Collect } \\
\text { Evaluation } \\
\text { Data }\end{array}$ & $\begin{array}{c}\text { Methods } \\
\text { Evaluation } \\
\text { Techniques }\end{array}$ & $\begin{array}{c}\text { Review } \\
\text { Decide } \\
\text { Acr }\end{array}$ \\
\hline
\end{tabular}

Gambar 2. Model Pengembangan IDI

Ada tiga tahapan dalam model IDI yaitu: (define) pendefinisian atau analisis kebutuhan, (develop) pengembangan, dan evaluasi (evaluate). Seperti terlihat dalam Gambar 2 model pengembangan IDI. Tahap pertama yaitu define yang dimulai dengan analisis kebutuhan terhadap rubrik penilaian otentik dalam mata kuliah materi SKI dan Pembelajarannya. Tahap kedua adalah tahap pengembangan (develop) yang berisikan langkah-langkah atau metode yang digunakan dan penyusunan prototipe, sedangkan tahap ketiga yaitu tahap evaluasi/ penilaian yang berisikan validasi dari tim pakar dan uji praktikalitas dari mahasiswa terhadap rubrik penilaian teman sejawat.

Peneliti memilih model IDI karena peneliti memandang bahwa model ini sesuai dengan masalah yang melatarbelakangi penelitian ini. Dengan adanya analisis kebutuhan, peneliti berharap dengan menggunakan model ini dapat dikembangkan sebuah rubrik penilaian otentik yang valid, reliabel dan praktis untuk mengukur semua aspek dalam pelaksanaan proses perkuliahan mata kuliah materi SKI dan pembelajarannya.

\section{Prosedur Pengembangan}

Sejalan dengan model pengembangan IDI, peneliti membuat rancangan prosedur pengembangan rubrik penilaian otentik ini pada tiga tahapan, yaitu: (1) Tahap pendefenisian (Define); (2) Tahap Pengembangan (Prototype); (3) Tahap Penilaian (Evaluate)

Rancangan penelitian dapat diuraikan pada tahap prosedural sebagai berikut: (1) Tahap pendefenisian (define) dilakukan untuk mendapatkan gambaran kondisi dilapangan. Pada tahap ini dilakukan langkah-langkah sebagai berikut: (a) Analisis kebutuhan yang bertujuan untuk mengetahui kebutuhan jurusan Pendidikan Agama Islam (PAI) dalam mata kuliah materi SKI dan pembelajarannya dalam menggunakan rubrik penilaian yang dapat mengukur semua aspek keterampilan/performance mahasiswa terutama mata kuliah yang sifatnya praktek. (b) Tahap Evaluasi, pada tahap ini dilakukan validasi produk rubrik penilaian otentik pada mata kuliah materi SKI dan pembelajarannya, yang akan divalidasi oleh tiga orang dosen (validator) yang mempunyai kompetensi sesuai dengan bidang keahliannya.Sesuai dengan pendapat (Sugiyono, 2011:352) jumlah tenaga ahli yang digunakan minimal 3 orang dan umunya mereka yang telah bergelar Magister sesuai dengan lingkup 
yang diteliti. (2) Tahap Pengembangan (Develop), hasil analisis pada tahap pendefenisian digunakan untuk merancang rubrik penilaian otentik untuk mata kuliah materi SKI dan pembelajarannya. Pada tahap pengembangan ini terdapat dua tahap yaitu: tahap perancangan tes (prototype) yaitu menentukan tujuan dalam pengembangan rubrik penilaian otentik. Rubrik penilaian otentik yang akan dikembangkan dalam penelitian ini bertujuan agar terciptanya sebuah rubrik yang dapat mengukur semua aspek performance siswa dan tahap validasi pakar yang dalam pengembangan rubrik penilaian otentik, instrumen yang telah dirancang, sebelum diujicobakan kelapangan perlu dilakukan penilaian kualitas rubrik. Penilaian dari segi kualitatif ini dilakukan dengan cara validasi oleh pakar, hal ini dilakukan agar mendapatkan masukan kritis sebagai upaya untuk meminimalisasi kesalahan atau kekurangan, tahapan ini mutlak dan penting dalam R\&D agar produk yang dihasilkan benar-benar bebas dari kesalahan atau kekeliruan (Putra, 2011:113).

Untuk validitas isi kegiatan validasi dilakukan dalam bentuk mengisi lembar validasi dan diskusi sampai diperoleh rubrik penilaian otentik yang valid dari segi kualitatif dan layak untuk dipakai dalam proses perkuliahan.

Dalam penelitian ini validator yang dimaksudkan adalah orang yang ahli dalam bidang evaluasi pendidikan dan dosen Jurusan. Setelah meminta kesediaan validator untuk melihat kelayakan rubrik yang telah dibuat, maka dilakukan revisi sesuai saran-saran yang diberikan oleh validator. Perevisian rubrik ini akan berlangsung sampai validator menyatakan tes tersebut layak untuk dipakai. Validasi rubrik penilaian otentik yang dikembangkan, dilakukan oleh 3 orang Pakardalam bidang penelitian dan evaluasi pendidikan2 orang dan bidang pendidikan 1 orang. (3) Tahap Penilaian (evaluate), pada tahap penilaian ini rubrik yang telah lulus uji validasi pakar kemudian direvisi sampai nanti rubrik yang dirancang dapat digunakan sesuai dengan harapan yaitu valid, reliabel dan praktis digunakan untuk mengukur performance dan unjuk kerja mahasiswa. Langkah-langkah penelitian tersebut dapat disajikan dalam gambar sebagai berikut:

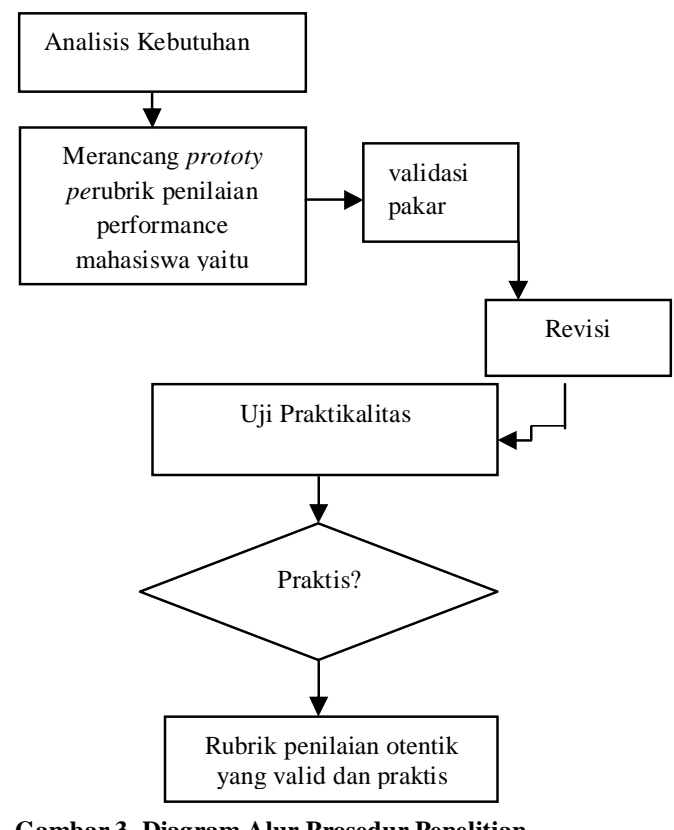

Gambar 3. Diagram Alur Prosedur Penelitian

\section{Instrumen Pengumpulan Data}

a. Lembar Validasi Pakar

Lembar validasi pakar digunakan untuk mengumpulkan data hasil valiadasi oleh pakar terhadap rubrik penilaian otentik yang sedang dikembangkan.

b. Angket

Angket digunakan untuk mengumpulkan data praktikalitas dari rubrik penilaian otentik yang dikembangkan, angket diberikan kepada mahasiswa Pendidikan Agama Islam.

\section{Teknik Analisa Data}

\begin{tabular}{l}
\multicolumn{1}{c}{ Rubrik penilaian otentik yang } \\
dikembangkan untuk pelaksanaan \\
pembelajaran materi SKI dan \\
pembelajarannya untukmahasiswayang \\
akan dikembangkan, maka tahapan \\
selanjutnya adalah menganalisis, dan \\
memvalidasiinstrumen yang dibuat.
\end{tabular}


Analisis Data Hasil Validasi Pakar.

Data hasil validasi oleh pakar dianalisis menggunakan statistik deskriptif, data kelayakan intrumen ini berupa rentangan nilai 1-4. Teknik Analisis penilaian validator/pakar menggunakan rumus:

$$
\mathbf{R}=\underset{\mathbf{n m}}{\sum \mathbf{V}_{\mathrm{ij}}} \text { (Muliyardi, 2006:82) }
$$

Keterangan:

\begin{tabular}{|l|l|l|}
\hline $\mathrm{R}$ & $:$ & Rerata \\
\hline $\mathrm{V}$ & $:$ & Skor hasil penilain para ahli \\
\hline $\mathrm{n}$ & $:$ & Banyaknya pakar yang memvalidasi \\
\hline $\mathrm{m}$ & $:$ & Banyaknya kriteria \\
\hline
\end{tabular}

Rerata yang didapatkan

dikonfirmasikan dengan kriteria yang ditetapkan. Cara mendapatkannya dengan menggunakan langkah-langkah sebagai berikut: (1) Rentangan skor mulai dari 15; (2) kritera dibagi atas 5 tingkatan yaitu sangat valid, valid, cukup valid, kurang valid dan tidak valid; (3) rentangan skor dibagi menjadi lima kelas dengan mengikuti prosedur diatas dapat dikreteriakan sebagai berikut (Muliyadi, 2006:82) :

$\mathrm{R}>3.20 \quad$ : sangat valid

$2.40<\mathrm{R} \leq 3.20$ : valid

$1.60<\mathrm{R} \leq 2.40$ : cukup valid

$0.80<\mathrm{R} \leq 1.60$ : kurang valid

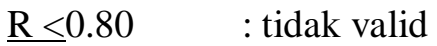

\section{Analisis Data Praktikalitas}

Analisis data angket praktikalitas instrumen dideskripsikan dengan teknik analisis frekuensi data dengan rumus sebagai berikut:

Skor Nilai Ideal $=\underline{\text { Skor Diperoleh }} \times 100 \%$

Skor Maksimal

Kategori praktikalitas instrumen sebagai berikut:

$80-100 \%=$ sangat praktis

$60-79 \%=$ praktis

$40-59 \%=$ cukup praktis

$20-39 \%=$ kurang praktis

$0-19 \%=$ tidak praktis (Riduwan, 2009: 138)

\section{HASIL PENELITIAN}

Dalam Bab ini disajikan hasil penelitian pengembangan rubrik penilaian otentik pada mata kuliah SKI dan pembelajarannya Berdasarkan prosedur pengembangan tes yang dikemukan pada Bab 3, maka deskripsi hasil penelitian ini dijabarkan dalam 3 bagian yaitu: tahap pendefinisian (define), tahap pengembangan (develop), dan tahap evaluasi (evaluate)

\section{Hasil Analisis Tahap Pendefinisian (Define)}

Dalam analisis tahapan pendefinisian berisikan analisis kebutuhan, analisis hasil observasi pada mata kuliah materi SKI dan pembelajarannya, analisis instrumen yang dipakai terhadap penilaian kinerja mahasiswa dalam mata kuliah SKI dan pembelajarannya. (1) Hasil analisis kebutuhan, dalam proses perkuliahan materi SKI dan pembelajarannya dimana dalam karakter mata kuliahnya adalah dalam bentuk praktek dan unjuk kerja mahasiswa terhadap materi SKI yang sesuai dengan silabus yang ada disekolah/dimadrasah.

Dalam hal ini instrumen dalam bentuk instrumen berupa rubrik penilaian otentik merupakan jenis yang paling dibutuhkan, untuk mengukur kompetensi mahasiswa sebagai calon guru disekolah/ di madrasah. Berpatokan kepada berbagai keunggulan yang dimiliki oleh rubrik penilaian otentik ini maka mahasiswa bisa mengetahui secara keseluruhan kompetensi yang dimilikinya dalam unjuk kerja dan penilaianya bisa dilakukan oleh dosen dan bisa dilakukan oleh teman sejawat dan oleh mahasiswa itu sendiri. (2) Hasil analisis observasi, dari hasil pengamatan/ observasi yang penulis lakukandalam proses pembelajaran bahwa rubrik penilaian yang digunakan oleh dosen belum mampu menjangkau atau menilai seluruh aspek kompetensi mahasiswa dalam melakukan unjuk kerja, penilaian yang dilakukan oleh dosen hanya sebatas penilain pada aspek psikomotor atau keterampilan siswa pada saat praktek di depan dikelas dengan bebarapa indikator saja. 


\section{Hasil Analisis Tahap Pengembangan (Develop)}

Berdasarkan hasil analisis pada tahap pendefinisian, maka dirancang rubrik penilaian otentik pada mata kuliah materi SKI dan pembelajarannya. Pada tahap pengembangan ini dilakukan 2 tahap yaitu: (1) Hasil tahap perancangan (Prototype), Pada tahap perancangan tes dilakukan dengan langkah-langkah yaitu: 1) menetapkan tujuan pengembangan rubrik. Rubrik yang dirancang di tujukan untuk menilai produk dan unjuk kerja mahasiswa. 2) menyusun rubrik penilaian otentik, 3) merancangalternatif pilihan jawaban dalam rubrik, dan skor dari masing alternatif pilihan jawaban dan 4) menyusun pedoman peskoran; (2) Hasil analisis tahap validasi pakar, rubrik penilaian otentik yang telah selesai di rancang, tahapan selanjutnya sebelum ujicoba terbatas pada mahasiswa yang mengambil mata kuliah materi SKI dan pembelajarannya selanjutnya tahap validasi pakar. Rubrik yang telah selesai dirancang di konsultasikan dan didiskusikan dengan pakar, untuk mendapatkan masukan kritis, demi perbaikan kualitas isi dari rubrik dan untuk meningkatkan content validity. Berikut saran-saran perbaikan dari pakar yang ikut memvalidasi rubrik otentik tersebut.

\begin{tabular}{|c|c|}
\hline $\begin{array}{c}\text { No } \\
\text { Pakar }\end{array}$ & Saran Perbaikan \\
\hline 1 & 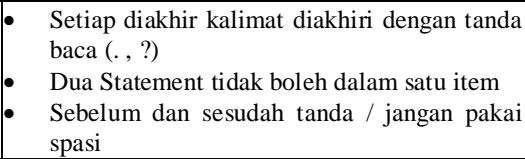 \\
\hline 2 & $\begin{array}{l}\text { - Petunjuk Pengisian: kata "praktek } \\
\text { pembelajaran" sebaiknya diganti "praktek } \\
\text { mengajar" } \\
\text { Rubrik penilaian untuk skor 2, } \\
\text { keterangannya sebaikya tidak mengandung } \\
\text { kata dan, cukup dengan jika kadang-kadang } \\
\text { melakukan } \\
\text { Pada bagian indikator penilaian item } 17 \text { dan } \\
18 \text { masing-masing berhubungan dengan } \\
\text { penggunaan media, sebaiknya digabung saja } \\
\text { untuk tidak menyulitkan saat melakukan } \\
\text { penilaian, sehingga menjadi: penggunaan } \\
\text { media dalam pembelajaran yang meliputi } \\
\text { ketepatan penggunaan dan kejelasan secara } \\
\text { audia atau visual }\end{array}$ \\
\hline 3 & Rubrik harus disusun secara sistematis dan \\
\hline
\end{tabular}

\begin{tabular}{|l|l|}
\hline & diurut berdasarkan kompetensi \\
& Usahakan bahasa dalam rubrik tidak ambigu \\
\hline
\end{tabular} Sumber: Data Primer Hasil Validasi Pakar

Rubrik penilaian otentik yang telah di dikonsultasikan dengan pakar diperbaiki sesuai dengan saran validator. Perbaikan yang dilakukan diantaranya masalah teknik penulisan. Perbaikan dari segi konstruksi dan masalah bahasa.

Setelah rubrik penilaian otentik tersebut diperbaiki kemudian dikonsultasikan kembali dengan pakar. Hasil dari lembar validasi pakar di uraikan dalam tabel sebagai berikut:

Tabel 2 : Hasil Uji Validasi Pakar Pengembangan Rubrik Penilaian Otentik

\begin{tabular}{|c|c|c|c|}
\hline No & Aspek yang Ditelaah & Nilai & $\begin{array}{c}\text { Kategor } \\
\mathbf{i}\end{array}$ \\
\hline \multirow[t]{5}{*}{$\mathbf{A}$} & \multicolumn{3}{|l|}{ ASPEK MATERI } \\
\hline & $\begin{array}{l}\text { 1. Rubrik yang dibuat } \\
\text { sesuai dengan standar } \\
\text { penyusunan sebuah } \\
\text { rubrik penilain }\end{array}$ & 4 & $\begin{array}{l}\text { Sangat } \\
\text { Valid }\end{array}$ \\
\hline & \begin{tabular}{ll} 
2. & \multicolumn{2}{l}{ Indikator yang dinilai } \\
sesuai dengan prinsip \\
penilaian (urgensi, \\
relevansi, dan \\
kontiniutas & dan \\
komprehensif) & \\
\end{tabular} & 3.3 & $\begin{array}{l}\text { Sangat } \\
\text { Valid }\end{array}$ \\
\hline & $\begin{array}{l}\text { 3. Indikator yang dinilai } \\
\text { mengukur semua } \\
\text { aspek performance } \\
\text { dan unjuk kerja } \\
\text { mahasiswa } \\
\end{array}$ & 3.3 & $\begin{array}{c}\text { Sangat } \\
\text { Valid }\end{array}$ \\
\hline & $\begin{array}{c}\text { Rubrik yang disusun } \\
\text { sistematis }\end{array}$ & 3.7 & $\begin{array}{c}\text { Sangat } \\
\text { Valid }\end{array}$ \\
\hline \multirow[t]{4}{*}{ B } & ASPEK KONSTRUKSI & & \\
\hline & $\begin{array}{ll}\text { 5. Indikator penilaian } \\
\text { dirumuskan dengan } \\
\text { singkat, jelas dan } \\
\text { tegas }\end{array}$ & 3 & Valid \\
\hline & $\begin{array}{llr}\text { 6. } & \begin{array}{l}\text { Penyusunan rubrik } \\
\text { dilengkapi }\end{array} & \begin{array}{r}\text { dengan } \\
\text { petunjuk yang jelas }\end{array} \\
\end{array}$ & 4 & $\begin{array}{l}\text { Sangat } \\
\text { Valid }\end{array}$ \\
\hline & $\begin{array}{llr}\text { 7. } & \begin{array}{l}\text { Penyusunan } \\
\text { dilengkapi }\end{array} & \text { rubrik } \\
\text { dengan } \\
\text { contoh } & \text { penskoran } \\
\text { yang jelas } & \\
\end{array}$ & 4 & $\begin{array}{l}\text { Sangat } \\
\text { Valid }\end{array}$ \\
\hline $\mathbf{C}$ & Aspek bahasa & & \\
\hline & $\begin{array}{llr}\text { 8. } & \text { Rubrik yang dibuat } \\
\text { menggunakan kaidah } \\
\text { bahasa Indonesia } \\
\text { yang baik. }\end{array}$ & 2.7 & Valid \\
\hline & $\begin{array}{l}\text { 9. Menggunakan bahasa } \\
\text { yang komunikatif }\end{array}$ & 3.7 & $\begin{array}{l}\text { Sangat } \\
\text { Valid } \\
\end{array}$ \\
\hline & $\begin{array}{llr}\text { 10. } & \text { Bahasa } & \text { yang } \\
\text { digunakan } & \text { sederhana, } \\
\text { lugas, } & \text { mudah } \\
\text { dipahami } & \\
\end{array}$ & 3.3 & $\begin{array}{l}\text { Sangat } \\
\text { Valid }\end{array}$ \\
\hline \multicolumn{2}{|c|}{ Total } & 35 & \\
\hline \multicolumn{2}{|c|}{ Rata-rata } & 3.5 & \\
\hline & Kategori & \multicolumn{2}{|c|}{ Sangat Valid } \\
\hline
\end{tabular}


Dalam tahap validasi ahli terdapat 3 aspek yang ditelaah dalam rubrik yang dikembangkan yaitu aspek materi, aspek konstruksi dan aspek bahasa. Hasil validasi ketiga orang pakar menunjukkan bahwa rubrik penilaian otentik ini memiliki kriteria sangat valid pada aspek materi dengan rata-rata 3.57. Pada aspek konstruksi rubrik penilaian otentik juga memiliki kriteria sangat valid dengan ratarata 3.67 sedangkan pada aspek bahasa diperoleh rata-rata 3.23 dengan kategori sangat valid. Jadi secara keseluruhan rubrik penilaian otentik yang dikembangkan berdasarkan hasil validasi pakar memiliki kriteria sangat valid dengan nilai rata-rata 3.53 .

\section{Hasil Analisis Tahap Evaluasi (Evaluate)}

Pada tahapan penilaian (Evaluasi) kegiatan dipusatkan untuk mengevaluasi apakah rubrik penilaian otentik yang telah dirancang dapat digunakan sesuai dengan harapan yaitu validdan praktis untuk mengukur hasil belajar mahasiswa dalam mata kuliah materi SKI dan pembelajarannya. (1) Hasil analisis praktikalitas rubrik, Praktikalitas dari pengembangan rubrik penilaian otentik dalam penilaian teman sejawatdi peroleh dari pengembangan produk yang telah dibuat kapada mahasiswa dalam mata kuliah materi SKI dan Pembelajarannya dari Hasil perhitungan data praktikalitas rubrik penilaian otentik yang disusun di rangkum dalam Tabel 3 sebagai berikut:

Tabel 3. Praktikalitas Rubrik Penilaian Otentik

\begin{tabular}{|c|c|c|c|}
\hline No & $\begin{array}{l}\text { Aspek yang } \\
\text { ditelaah }\end{array}$ & Nilai & Kriteria \\
\hline 1. & $\begin{array}{l}\text { Rubrik yang } \\
\text { disusun } \\
\text { membantu } \\
\text { dosen dalam } \\
\text { menilai } \\
\text { performance } \\
\text { mahasiswa } \\
\text { secara } \\
\text { komprehens } \\
\text { if }\end{array}$ & 89.06 & $\begin{array}{l}\text { Sangat } \\
\text { Praktis }\end{array}$ \\
\hline 2. & $\begin{array}{l}\text { Rubrik yang } \\
\text { disusun }\end{array}$ & 90.63 & $\begin{array}{l}\text { Sangat } \\
\text { Praktis }\end{array}$ \\
\hline
\end{tabular}

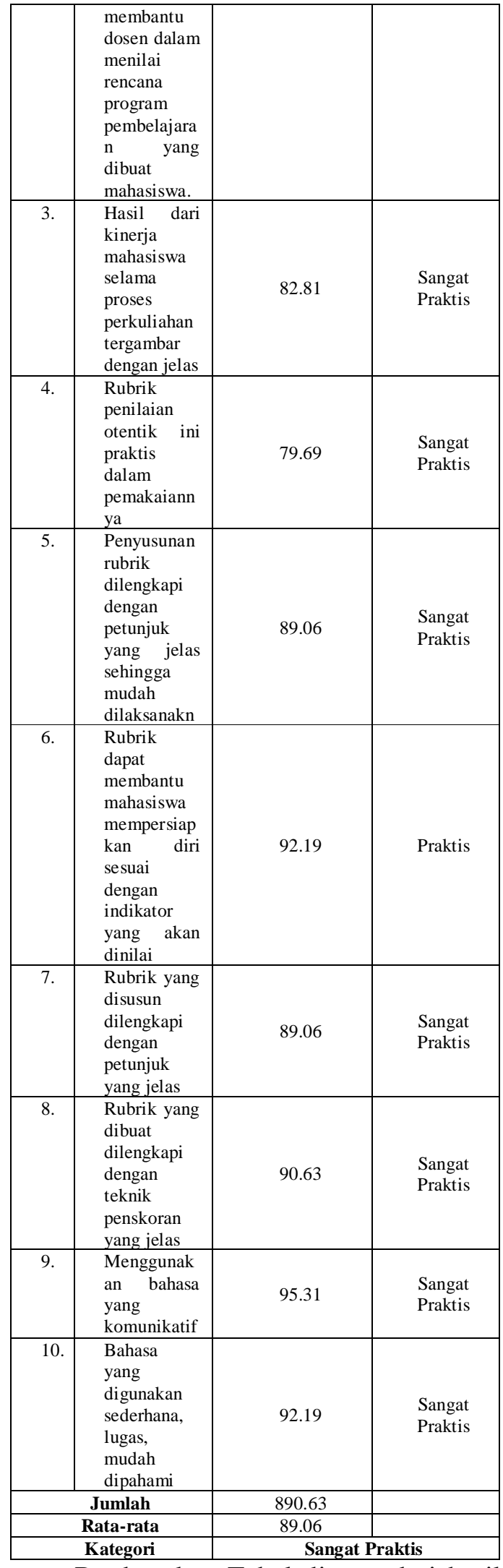

Berdasarkan Tabel di atas dari hasil analisis praktikalitas rubrikt penilaian 
otentik di ketahui bahwa rubrik ini sangat praktis untuk di gunakan, dengan jumlah nilai praktikalitas 890.63 dan rata-rata nilai kepraktisan 89.06 dengan kategori sangat praktis.

\section{PEMBAHASAN}

Hasil analisis tahapan evaluasi dari pengembangan rubrik penilaian otentik pada mata kuliah materi SKI dan pembelajarannya, menunjukkan bahwa rubrik penilaian otentik yang dikembangkan valid dan praktis untuk mengukur hasil belajar dan unjuk kerja mahasiswa. Analisis lanjut juga menunjukkan bahwa rubrik penilaian otentik yang dikembangkan merupakan rubrik yang praktis, digunakan oleh dosen yang mengampu mata kuliah materi SKI dan pembelajarannya dalam mengukur aspek kognitif, afektif dan psikomotor mahasiswa secara keseluruhan.

\section{Validitas Kontruk}

Rubrik penilaian otentik yang digunakan untuk mengukur hasil belajar mahasiswa, juga harus valid dari segi konstruk. Oleh karena itu rubrik penilaian otentik yang dikembangkan ini perlu dilakukan analisis validitas konstruk. Sama halnya dengan analisis validitas isi, analisis validitas konstruk juga digunakan pendapat dari ahli (judgment expert) (Sugiyono, 2010:3512). Hasil analisis oleh ahli menujukkan kalau rubrik ini sangat valid dengan beberapa perbaikan.

\section{Praktikalitas Rubrik Penilaian Otentik}

Praktikalitas rubrik penilaian otentik, diperoleh dari angket praktikalitas yang diberikan kepada tim pakar dari hasil analisis praktikalitas oleh validator membuktikan bahwa rubrik tersebut bersifat praktis untuk gunakan dalam mengukur performance siswa dalam proses perkuliahan materi SKI dan Pembelajarannyaserta mengukur produk kerja/tugas mahasiswa. Artinya semakin bagus rubrik yang diapakai dalam proses perkuliahan maka akan semakin evaluasi yang dilakukan dosen akan semakin objektif dan menyeluruh.

\section{KESIMPULAN}

Secara keseluruhan rubrik penilaian otentik yang dikembangkan berdasarkan hasil validasi pakar memiliki kriteria sangat valid dengan nilai rata-rata 3.53 , sedangkan analisis praktikalitas rubrik penilaian otentik diketahui bahwa rubrik ini sangat praktis untuk digunakan, dengan jumlah nilai praktikalitas 890.63 dan ratarata nilai kepraktisan 89.06 dengan kategori sangat praktis.

\section{DAFTAR PUSTAKA}

Aminul Hadin Harjono, Metodologi Penelitian Pendidikan, Semarang: Thoha Putra,1998

Abdul Madjid, Penilaian Otentik Proses dan Hasil Belajar, Bandung: PT Remaja Rosdakarya, 2014

Ambiyar, Pengukuran, Tes dalam Pendidikan, Padang : UNP Press, 2012.

Departemen Agama, Metodologi Pendidikan Agama, Jakarta: Dirjen Kelembagaan Agama Islam, 2002

Haryati, Mimin.Sistem penilaian Berbasis Kompetensi. Jakarta: Gaung Persada Press, 2007

Jemari Mardapi. 2008, Teknik Penyusunan Instrumen Tes dan Non Tes, Yogyakarta: Mitra Cendikia Press

Kunandar. Penilaian Autentik. Jakarta: Raja Grafindo Persada, 2013

Nana Sudjana, Penilaian Hasil Proses Belajar Mengajar, Bandung: PT Remaja Rosdakarya, 1999 
Suharsimi Arikunto, Prosedur Penelitian Suatu Pendekatan Praktik, Jakarta: Rineka Cipta, 1993

— Dasar- Dasar Evaluasi Pendidikan, Jakarta : PT Bumi Aksara, 2009

Sugiono, Metode Penelitian Pendidikan Pendekatan Kuantitatif, Kualitatif dan $R \& D$, Bandung: Alfabeta, 2011

Sukardi. Evaluasi Pendidikan. Jakarta: Bumi Aksara, 2008
Surapranata, Sumarna. Panduan Penulisan Tes Tertulis. Bandung: Rosda, 2005

Surapranata, Sumarna \& M. Hatta. Penilaian Portofolio. Bandung: Rosda, 2004

Slameto. Evaluasi Pendidikan, Jakarta : Bina Aksara, 1998

Yusuf, Muri. Asesmen dan Evaluasi Pendidikan. Padang: Process \& Product, 2011 